\title{
Peak of Electron Density in F2-Layer Parameters Variability at Quiet Days on Solar Minimum
}

\author{
Emmanuel Nanéma ${ }^{1,2 *}$, Moustapha Konaté ${ }^{2}$, Frédéric Ouattara ${ }^{2}$ \\ ${ }^{1}$ Centre National de la Recherche Scientifique et Technologique (CNRST), Institut de Recherche en Sciences Appliquées et \\ Technologies (IRSAT), Ouagadougou, Burkina Faso \\ ${ }^{2}$ Université Norbert ZONGO, Laboratoire de Recherche en Météorologie de l'Espace (LAREME), Koudougou, Burkina Faso \\ Email: *nanema_emmanuel@yahoo.fr
}

How to cite this paper: Nanéma, E., Konaté, M. and Ouattara, F. (2019) Peak of Electron Density in F2-Layer Parameters Variability at Quiet Days on Solar Minimum. Journal of Modern Physics, 10, 302-309. https://doi.org/10.4236/jmp.2019.103021

Received: February 1, 2019

Accepted: March 8, 2019

Published: March 11, 2019

Copyright (c) 2019 by author(s) and Scientific Research Publishing Inc. This work is licensed under the Creative Commons Attribution International License (CC BY 4.0).

http://creativecommons.org/licenses/by/4.0/

(c) (i) Open Access

\begin{abstract}
This study deals with Peak of electron density in F2-layer sensibility scale during quiet time on solar minimum. Peaks of electron density in F2-layer $(\mathrm{NmF} 2)$ values at the quietest days are compared to those carried out from the two nearest days (previous and following of quietest day). The study uses International Reference Ionosphere (IRI) for ionosphere modeling. The located station is Ouagadougou, in West Africa. Solar minimum of phase 22 is considered in this study. Using three core principles of ionosphere modeling under IRI running conditions, the study enables to carry out Peak of electron density in F2-layer values during the quietest days of the characteristic months for the four different seasons. These parameters are compared to those of the previous and the following of the quietest days (the day before and following each quietest selected day) at the same hour. The knowledge of $\mathrm{NmF} 2$ values at the quietest days and at the two nearest days enables to calculate the relative error that can be made on this parameter. This calculation highlights insignificant relative errors. This means that $\mathrm{NmF} 2$ values at the two nearest days of each quietest day on solar minimum can be used for simulating the quietest days' behavior. NmF2 values obtained by running IRI model have good correlation with those carried out by Thermosphere-Ionosphere-Electrodynamics-General Circulation Model (TIEGCM).
\end{abstract}

\section{Keywords}

Ionosphere, Peak of Electron Density in F2-Layer, Solar Cycle, Quiet Day, International Reference Ionosphere Model

\section{Introduction}

Ionosphere layer is an important site for radio waves reflection because of its 
composition in particles. This layer moves like a plasma and so, is electrically neutral. Solar radiations hit the particles in this layer and causes ionization. Ionization of particles in ionosphere layer due to solar radiations creates electrons and ions in the layer. Ionosphere composition in particles enables to determine the critical frequency of radio waves frequency of transmitters. Critical frequency of radio waves is closely linked to the density of electron in the F2-layer. Many works about ionosphere parameters determining have been done during these last years [1]-[10]. The main purpose of these different studies is to carry out ionosphere parameters for telecommunication, navigation, electrical disturbance predictions. Several models have been developed for ionosphere investigation. In previous studies, we used International Reference Ionosphere model, Thermosphere-Ionosphere-Electrodynamics General Circulation Model, and data [11]-[17] to carry out ionosphere parameters. The present study is focused on the calculation of relative error on Peak of electron density in F2-layer values at the limits of the quietest days for different seasons during solar minimum, compared to those of the quietest days. In this work, we calculate the relative error value on NmF2. The study is based on quiet time variation of solar cycle 22 at Ouagadougou station and uses International Reference Ionosphere (IRI) model for ionosphere investigation. 2012-version of IRI is used to run the model.

\section{Methodology-Fundamentals}

In this study, the minimum year (1985) of solar cycle 22 is considered for Peak of electron density in F2-layer behavior. Ionosphere modeling using IRI study is focused on the following three core principles: 1) The characteristic months are March, June, September and December for spring, summer, autumn and winter respectively. 2) The five quietest days of each characteristic month are used. 3) Solar minimum is characterized by sunspot number $\mathrm{Rz}<20$ and $\mathrm{Aa} \leq 20 \mathrm{nT}$. During quiet time conditions, the five quietest days characterize the whole month in each season. We consider the two nearest days (previous and following) of each quietest day in the characteristic month as the boundaries. Ouagadougou is located in West Africa. The following input parameters are used for running IRI model during solar minimum at the station: Year $=1985$, Longitude $=$ $358.5^{\circ} \mathrm{E}$, Latitude $=12.5^{\circ} \mathrm{N}$, Height $=500$, Stepsize $=1$. With above input parameters, $\mathrm{NmF} 2$ time values are obtained on "List Model data". These values are exported in an Excel file for plotting.

Table 1 highlights the five quietest days selected in each season on solar minimum.

\section{Results and Discussion}

Figures 1-4 present NmF2 time variation carried out by running IRI model under

Table 1. Retain days during solar minimum (1985) of cycle 22.

\begin{tabular}{cccc}
\hline March & June & September & December \\
\hline $9,13,21,22,25$ & $3,14,16,18,19$ & $2,3,4,5,29$ & $8,9,21,23,29$ \\
\hline
\end{tabular}




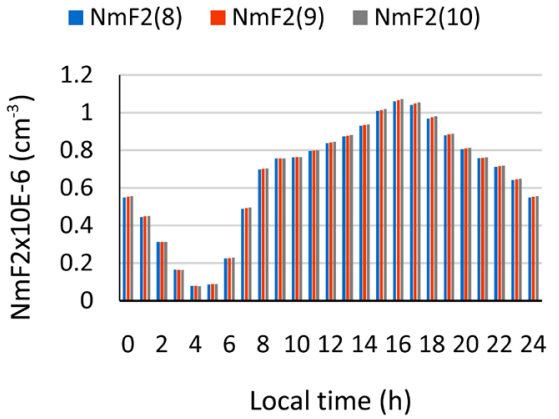

Panel a. NmF2 time variation on March 1985 $\left(8^{\text {th }}, 9^{\text {th }}, 10^{\text {th }}\right)$

$\square \mathrm{NmF2}(12) \quad \square \mathrm{NmF2}(13) \quad \mathrm{NmF2}$ (14)

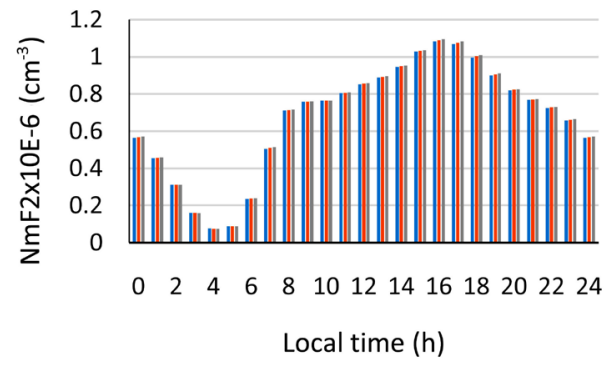

Panel c. NmF2 time variation on March 1985 $\left(12^{\text {th }}, 13^{\text {th }}, 14^{\text {th }}\right)$

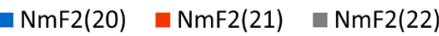

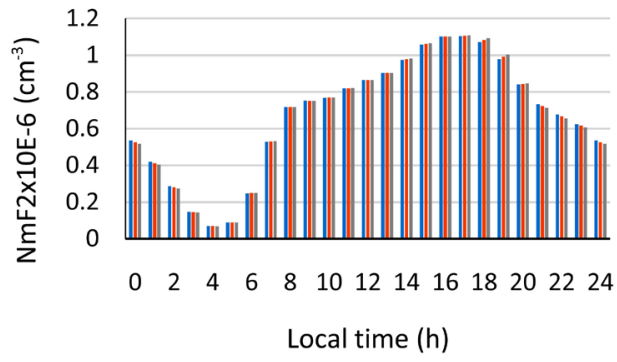

Panel e. NmF2 time variation on March 1985 $\left(20^{\text {th }}, 21^{\text {st }}, 22^{\text {nd }}\right)$

Figure 1. NmF2 time variation on March 1985.

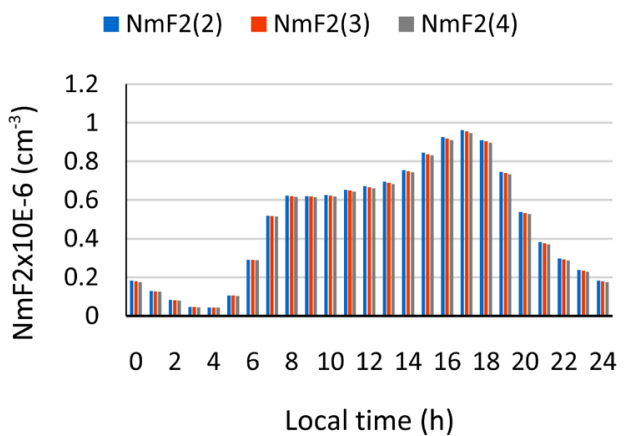

Panel a. NmF2 time variation on June 1985 $\left(2^{\text {nd }}, 3^{\text {rd }}, 4^{\text {th }}\right)$ $\square \mathrm{NmF2}(21) \square \mathrm{NmF2}(22) \square \mathrm{NmF2}(23)$

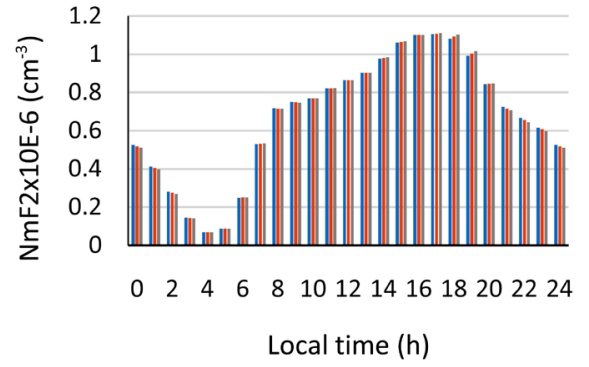

Panel b. NmF2 time variation on March 1985 $\left(21^{\text {st }}, 22^{\text {nd }}, 23^{\text {rd }}\right)$

$\square \mathrm{NmF2}(24) \quad \mathrm{NmF2}(25) \quad \mathrm{NmF2}(26)$

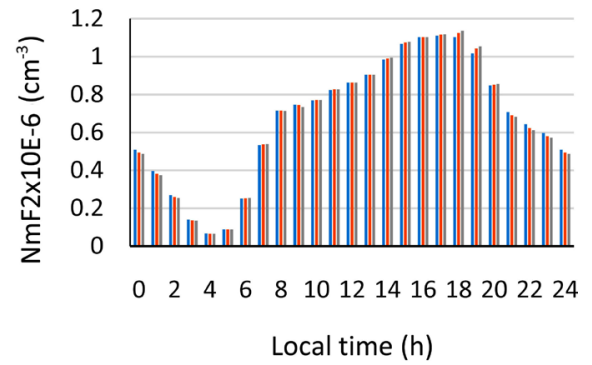

Panel d. NmF2 time variation on March 1985 $\left(24^{\text {th }}, 25^{\text {th }}, 26^{\text {th }}\right)$ $\square \mathrm{NmF2}(17) \quad \mathrm{NmF2}(18) \quad \mathrm{NmF2}(19)$

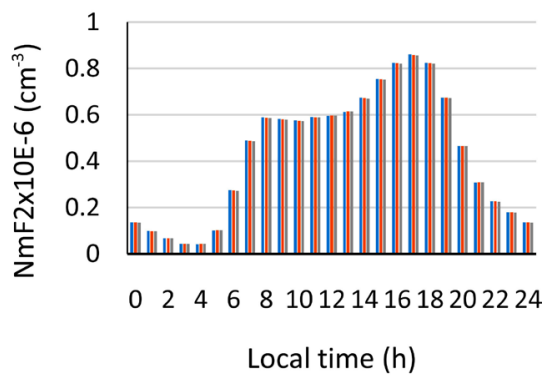

Panel b. NmF2 time variation on June 1985 $\left(17^{\text {th }}, 18^{\text {th }}, 19^{\text {th }}\right)$ 


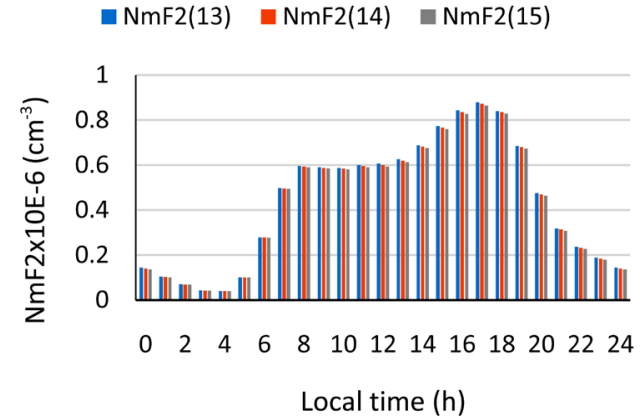

Panel c. NmF2 time variation on June 1985 $\left(13^{\text {th }}, 14^{\text {th }}, 15^{\text {th }}\right)$

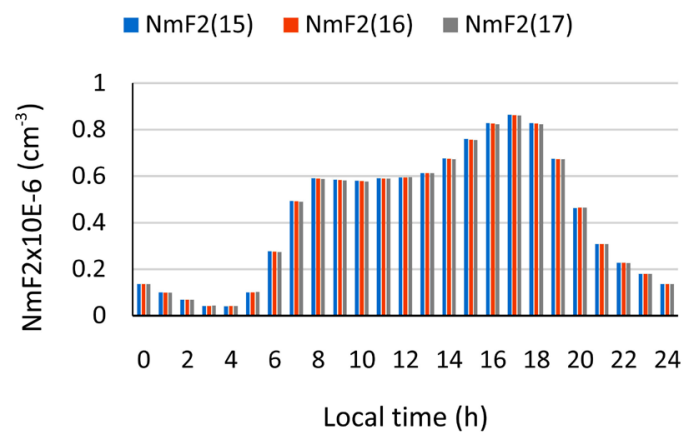

Panel e. NmF2 time variation on June 1985 $\left(15^{\text {th }}, 16^{\text {th }}, 17^{\text {th }}\right)$

Figure 2. NmF2 time variation on June 1985.

$\square \mathrm{NmF2}(1) \quad \square \mathrm{NmF2}(2) \quad \square \mathrm{NmF2}(3)$

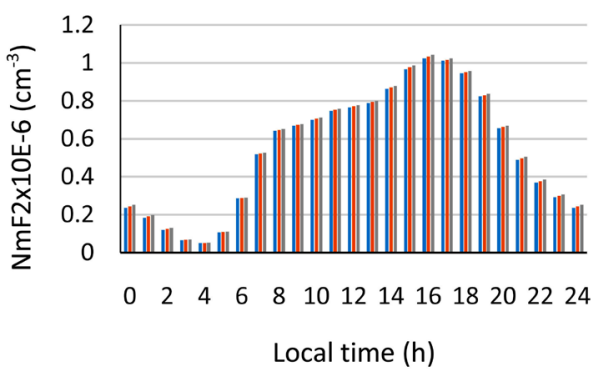

Panel a. NmF2 time variation on September 1985 $\left(1^{\text {st }}, 2^{\text {nd }}, 3^{\text {rd }}\right)$

$\square \mathrm{NmF2}(2) \quad \mathrm{NmF2}(3) \quad \square \mathrm{NmF2}(4)$

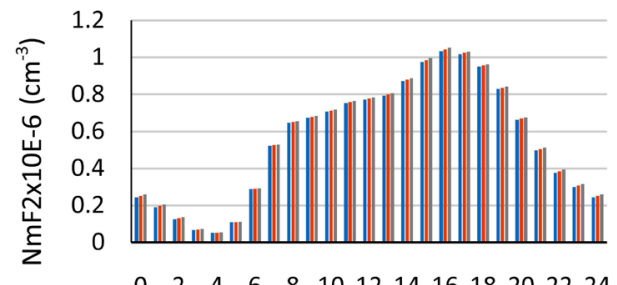

Local time $(\mathrm{h})$

Panel c. NmF2 time variation on September 1985 $\left(2^{\text {nd }}, 3^{\text {rd }}, 4^{\text {th }}\right)$ $\square \mathrm{NmF2}(18) \quad \mathrm{NmF2}(19) \quad \mathrm{NmF2}(20)$

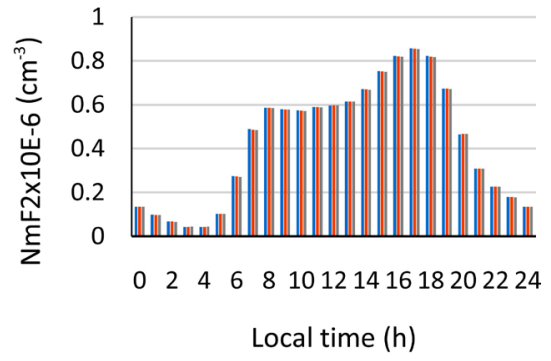

Panel d. NmF2 time variation on June 1985 $\left(18^{\text {th }}, 19^{\text {th }}, 20^{\text {th }}\right)$

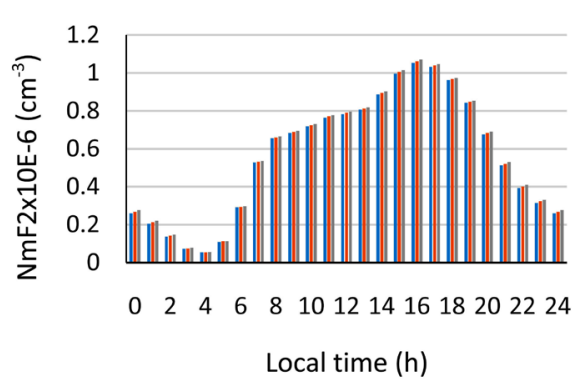

Panel b. NmF2 time variation on September 1985 $\left(4^{\text {th }}, 5^{\text {th }}, 6^{\text {th }}\right)$

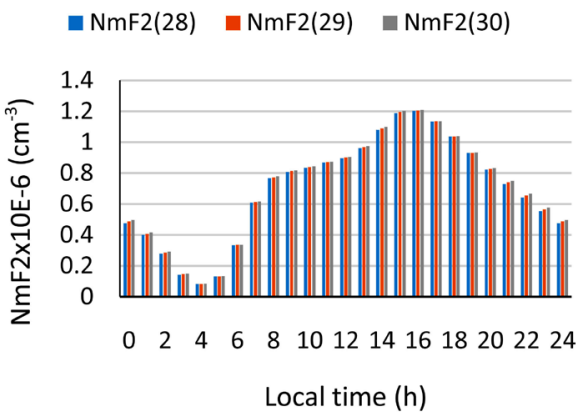

Panel d. NmF2 time variation on September 1985 $\left(28^{\text {th }}, 29^{\text {th }}, 30^{\text {th }}\right)$ 


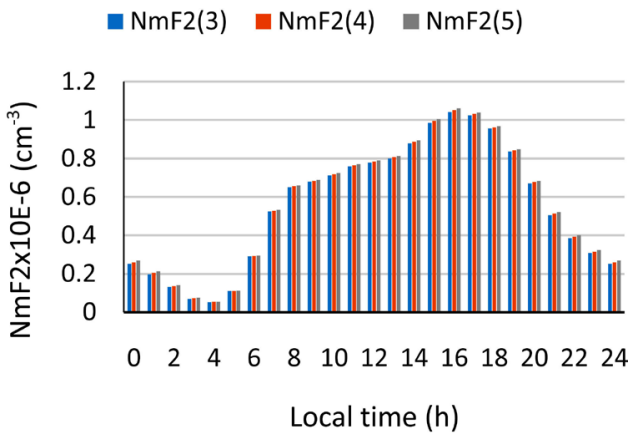

Panel e. NmF2 time variation on September 1985 $\left(3^{\text {rd }}, 4^{\text {th }}, 5^{\text {th }}\right)$

Figure 3. NmF2 time variation on September 1985.

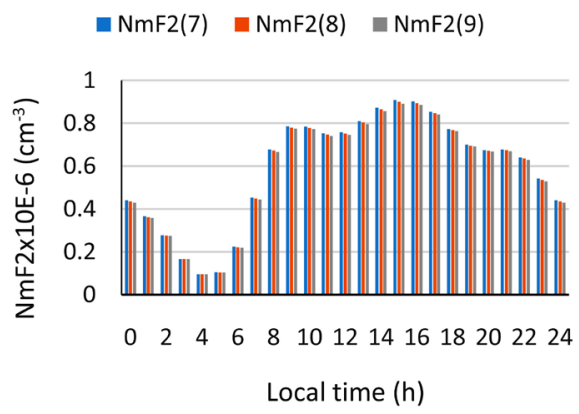

Panel a. NmF2 time variation on December 1985 $\left(7^{\text {th }}, 8^{\text {th }}, 9^{\text {th }}\right)$

$\square \mathrm{NmF2}(8) \quad \mathrm{NmF2}(9) \quad \mathrm{NmF2}(10)$

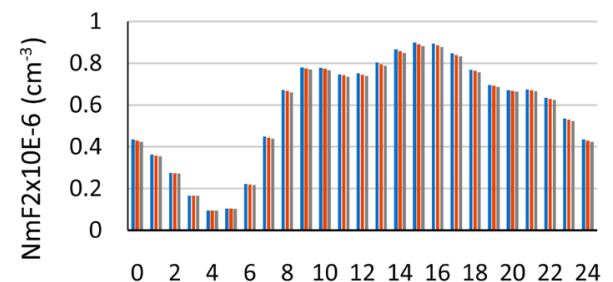

Local time $(\mathrm{h})$

Panel c. $\mathrm{NmF} 2$ time variation on December 1985 $\left(8^{\text {th }}, 9^{\text {th }}, 10^{\text {th }}\right)$

$\mathrm{NmF2}(20) \quad \mathrm{NmF2}(21) \quad \mathrm{NmF2}(22)$

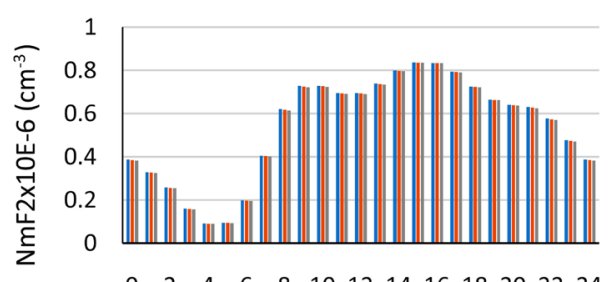

Local time $(\mathrm{h})$

Panel e. NmF2 time variation on December 1985 $\left(20^{\text {th }}, 21^{\text {st }}, 22^{\text {nd }}\right)$

Figure 4. NmF2 time variation on December 1985.

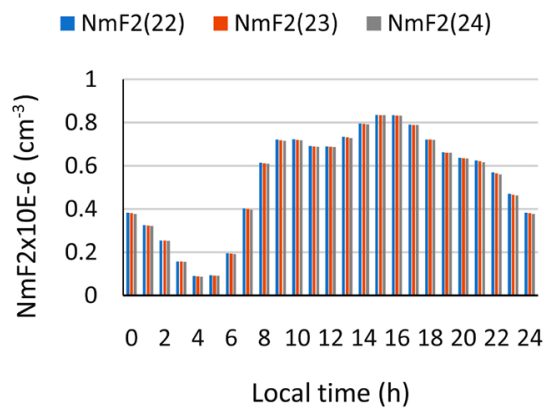

Panel b. NmF2 time variation on December 1985 $\left(22^{\text {nd }}, 23^{\text {rd }}, 24^{\text {th }}\right)$

$\square \mathrm{NmF2}(28) \quad \mathrm{NmF2}(29) \quad \mathrm{NmF2}(30)$

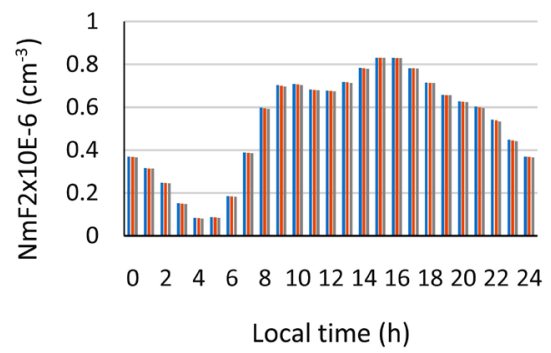

Panel d. NmF2 time variation on December 1985 $\left(28^{\text {th }}, 29^{\text {th }}, 30^{\text {th }}\right)$ 
its 2012-version for the retain days previously found in Table 1. On each figure, we present NmF2 time profiles on five different panels. Each panel highlights $\mathrm{NmF} 2$ time variations for three days that are the quietest day, the previous and the following day.

Relative error on Peak of electron density parameter in F2-layer is calculated by the following Equation (1):

$$
\frac{\Delta \mathrm{NmF} 2_{\mathrm{i}}}{\mathrm{NmF} 2_{\mathrm{i}}}=\frac{\left|\mathrm{NmF} 2_{\mathrm{i}}(\mathrm{D})-\mathrm{NmF} 2_{\mathrm{i}}(\mathrm{D} \pm 1)\right|}{\mathrm{NmF} 2_{\mathrm{i}}(\mathrm{D})}
$$

In Equation (1), $\mathrm{NmF}_{\mathrm{i}}(\mathrm{D})$ is the Peak of electron density value at $\mathrm{i}$ hour for $\mathrm{D}$-day. $\mathrm{D}$-day is the quietest day. $(\mathrm{D} \pm 1)$ are respectively the previous $(\mathrm{D}-1)$ and the following $(D+1)$ day of the quietest day. $i \in[0,24]$. The step for $i$ values variation is 1 .

Calculating the relative error on Peak of electron density in F2-layer for Figures 1-4 corresponding to March (spring), June (summer), September (autumn) and December (winter) gives the following ranges:

On March 1985:

$$
\frac{\Delta \mathrm{NmF} 2_{\mathrm{i}}}{\mathrm{NmF} 2_{\mathrm{i}}} \in[0 \%, 4 \%]
$$

On June 1985:

$$
\frac{\Delta \mathrm{NmF} 2_{\mathrm{i}}}{\mathrm{NmF} 2_{\mathrm{i}}} \in[0 \%, 2 \%]
$$

On September 1985:

$$
\frac{\Delta \mathrm{NmF} 2_{\mathrm{i}}}{\mathrm{NmF} 2_{\mathrm{i}}} \in[0 \%, 4 \%]
$$

On December 1985:

$$
\frac{\Delta \mathrm{NmF} 2_{\mathrm{i}}}{\mathrm{NmF} 2_{\mathrm{i}}} \in[0 \%, 1 \%]
$$

The range of $\frac{\Delta \mathrm{NmF} 2_{\mathrm{i}}}{\mathrm{NmF2} 2_{\mathrm{i}}}$ variation given by (2), (3), (4) and (5) is inferior to 4\%. Peak of electron density in F2-layer values vary slightly from the quietest day to its two nearest selected days. This means that $\mathrm{NmF} 2_{\mathrm{D}-1} \sim \mathrm{NmF} 2_{\mathrm{D}} \sim$ $\mathrm{NmF} 2_{\mathrm{D}+1}$ at the same time Calculated relative error at each hour between the quietest day and its two nearest days is inferior to $4 \%$ for $\mathrm{NmF} 2$. However, $\mathrm{NmF} 2$ value is a multiple of $10^{5} \mathrm{~cm}^{-3}$. In each panel, a variation of $4 \%$ is insensible on $\mathrm{NmF} 2$ value. This enables to conclude that a $4 \%$ variation on $\mathrm{NmF} 2$ does not influence measurably Peak of electron density in F2-layer. So, using NmF2 value at the nearest days of quietest day doesn't introduce a sensitive error on this parameter.

\section{Conclusion}

In this study, Peak of electron density in F2-layer parameter is carried out by the 
use of IRI model. The study highlights insignificant relative errors on NmF2 carried out from the quietest days on solar minimum of phase 22 at Ouagadougou station. This means that using NmF2 values at the nearest days of each quietest day instead of those of the quietest day doesn't introduce significant error. The contribution of this study is the possibility to neglect the relative error on Peak of electron density in F2-layer parameter due by considering the value of this parameter at the limits of each quietest day on solar minimum at low latitudes. This means that we can use either NmF2 carried from the quietest day or those from the nearest days to characterize the quietest day behavior. For a next study, this method will be applied to NmF2 variability on solar maximum.

\section{Conflicts of Interest}

The authors declare no conflicts of interest regarding the publication of this paper.

\section{References}

[1] Pedatella, N.M., Forbes, J.M., Maute, A., Richmond, A.D., Fang, T.-W., Larson, K.M. and Millward, G. (2011) Journal of Geophysical Research, 116, A12309. https://doi.org/10.1029/2011JA016600

[2] Roble, R.G., Ridley, E.C., Richmond, A.D. and Dickinson, R.E. (1988) Geophysics Research Letter, 15, 1325-1328. https://doi.org/10.1029/GL015i012p01325

[3] Wang, W., Wiltberger, M., Burns, A.G., Solomon, S.C., Killeen, T.L., Maruyama, N. and Lyon, J.G. (2004) Journal of Atmospheric and Solar-Terrestrial Physics, 66, 1425-1441. https://doi.org/10.1016/j.jastp.2004.04.008

[4] Richmond, A.D., Ridley, E.C. and Roble, R.G. (1992) Geophysics Research Letter, 19, 601-604. https://doi.org/10.1029/92GL00401

[5] Burns, A.G., Wang, W., Killen, T.L. and Solomon, S.C. (2004) Journal of Atmospheric and Solar-Terrestrial Physics, 66, 1457-1468. https://doi.org/10.1016/j.jastp.2004.04.009

[6] Weimer, D.R. (2005) Journal of Geophysical Research, 110, A05306. https://doi.org/10.1029/2004JA010884

[7] Jin, S. and Park, J.U. (2007) Earth Planet Space, 59, 287-292. https://doi.org/10.1186/BF03353106

[8] Bittencourt, J.A. and Chryssafidis, M. (1994) Journal of Atmospheric and Solar-Terrestrial Physics, 56, 995-1009. https://doi.org/10.1016/0021-9169(94)90159-7

[9] Ouattara, F. and Rolland, F. (2011) Scientific Research and Essays, 6, 3609-3622. https://doi.org/10.5897/SRE10.1050

[10] Qian, L., Burns, A.G., Chamberlin, P.C. and Solomon, S.C. (2010) Journal of Geophysical Research, 115, A09311. https://doi.org/10.1029/2009JA015225

[11] Ouattara, F. and Nanéma, E. (2014) Physical Science International Journal, 4, 892-902. https://doi.org/10.9734/PSIJ/2014/9748

[12] Ouattara, F. (2013) Archives of Physics Research, 4, 12-18.

[13] Ouattara, F. and Nanéma E. (2013) Archives of Applied Science Research, 5, 55-61.

[14] Nanéma, E., Ouédraogo, I., Zoundi, C. and Ouattara, F. (2018) International Journal of Geosciences, 9, 572-578. https://doi.org/10.4236/ijg.2018.99033

[15] Nanéma, E., Gnabahou, D.A., Zoundi, C. and Ouattara, F. (2018) International 
Journal of Astronomy and Astrophysics, 8, 163-170. https://doi.org/10.4236/ijaa.2018.820311

[16] Nour, A.M., Frédéric, O., Louis, Z.J., Frédéric, G.A.M., Emmanuel, N. and François, Z. (2015) International Journal of Geosciences, 6, 201-208. https://doi.org/10.4236/ijg.2015.63014

[17] Nanéma, E., Zerbo, J.L., Konaté, M. and Ouattara, F. (2018) Journal of Scientific and Engineering Research, 5, 62-68. 